\title{
Untreated Childhood Brain Stem Glioma
}

National Cancer Institute

\section{Source}

National Cancer Institute. Untreated Childhood Brain Stem Glioma. NCI Thesaurus. Code C115923.

A finding of brain stem glioma in childhood that has not been treated. 